\title{
Assessment of effectiveness of workstations in the selected production line
}

\author{
Urszula Malaga-Toboła ${ }^{1}$, Maciej Kuboń, ${ }^{1,2}$ Dariusz Kwaśniewski ${ }^{1}$ Sławomir Kocira ${ }^{3}$ \\ ${ }^{1}$ Department of Production Organization, Logistics and Applied Computer Science, \\ University of Agriculture in Krakow, Poland \\ ${ }^{2}$ Institute of Technical Sciences, State Vocational East European Higher School in Przemyśl, Poland. \\ ${ }^{3}$ Department of Machinery Exploitation and Management of Production Processes, University of Life \\ Sciences in Lublin
}

\begin{abstract}
Workstations are organizational units defined in a system, which determine where and when production operations must be performed. Thus, they have defined loads, and operations performed thereon are evaluated based on the information to which places, where costs are formed, and to which types of activities they are ascribed. Workstations may include machines, people, production lines etc. The aim of the paper was to define effectiveness of operation of particular working stations which constitute a line for production of bread. The scope of the research covered the production line in a production establishment, namely a bakery. Based on the work schedule developed for particular workstations and documentation provided by the production site, a production capacity of the said line and its use and loading of particular workstations was defined. Analysis showed that the load of workstations was from 80 to $88 \%$. A low level of variability of the load proves high mutual relations between particular workstations which are characteristic for continuous lines.

Keywords: production capacity, loading, workstation, production, process
\end{abstract}

\section{Introduction}

The present market requirements force enterprises to constantly minimize the production time at maintaining a high quality of a product, namely, to achieve the highest possible production capacity [1]. This concept should be understood as the biggest number of products manufactured within the determined time. It results mainly from the efficiency of particular workstations. It also depends on many factors related to the work environment and on the machine infrastructure, i.e. technical capacities of machines and devices, manner of their use, technology and organization of production and changes of product features [2-5]. It may be considered in the context of the entire enterprise or a single machine. Therefore, the use of particular machines and devices has a significant impact on the production results [6,7]. A workstation is the smallest link of the production line. It includes all production factors, necessary for realization of particular tasks [8]. A specialization level of workstations and their loading is known as the production type. This, on the other hand, depends on the production organization type and results from frequency of their shift [9]. A continuus production is the most often used in bakeries since the amount of the needed product, which must be produced may be determined in advance. It enables more effective use of the worktime, machines, and devices. Appropriate use of workstations decides on the course of 
the entire production. Therefore, they must be properly adjusted to operations, which they are to perform, they need to have a precise aim of operation and the manner of performing the work [10]. However, finally the work results of particular workstations depend on the man, who carries out a number of indispensable actions and functions [11-13]. Correct performance of work results from proper organization of workstations. It means a correct equipment of stations, depending on the performed works and distribution of their elements according to the principle of ergonomics and ensuring proper service [14-17].

\section{Aim, research area and methods}

Production capacity is one of the basic measures of the results obtained by the enterprise. It means the largest amount of the product, which may be manufactured at a specified time, at the optimal use of the production factors and maintaining the quality that corresponds to standards.

The objective of the paper was to analyse the effectiveness of operation of particular workstations which constitute a production line of wheat bread. The effectiveness of operation was expressed though assessment of the production capacity and loading of workstations.

Tests were carried out in the production site located on the area of Małopolskie Voivodeship. Tests consisted in observation of treatments which are carried out on particular workstations and on reporting the time for operation of a specific station. Moreover, in order to complete the information, a guided survey with employees that operate particular stations was carried out. Based on the determined schedule, the size of the production and time structure i.e. available time, production time, stoppages time, duration of faults and set ups, and referential changes were used.

The production capacity was calculated as a product of the machines and devices capacity in production units and effective time of operation in a year, while its use as a ratio of the production size and production capacity.

\section{Research results and discussion}

Properly classified and prepared raw material, in the amount defined by a given provision guarantees high quality of bakery products.

Flour is the most important raw material, which is sieved to remove contamination. In the next step, the prepared and processed raw materials are mixed to form a dough. Dough is formed on a special bakery table after it is weighed up and portioned with a dough chunker. The next step in bread production is dough proofing which takes place in special proofers known also as proofing boxes. It consists in water vapour activity and maintenance of relevant temperature and humidity. During proofing, dough rises and changes its properties - it becomes more delicate and lighter. After the proofing process, it is decorated and refined. Before dough is placed in the oven, portions are taken out from the baskets and placed in special pots in which they are placed in the oven. In the first stage of baking, browning to produce a crust, fixes its shape and dehydration of the crust takes place (fig. 1) [18]. 


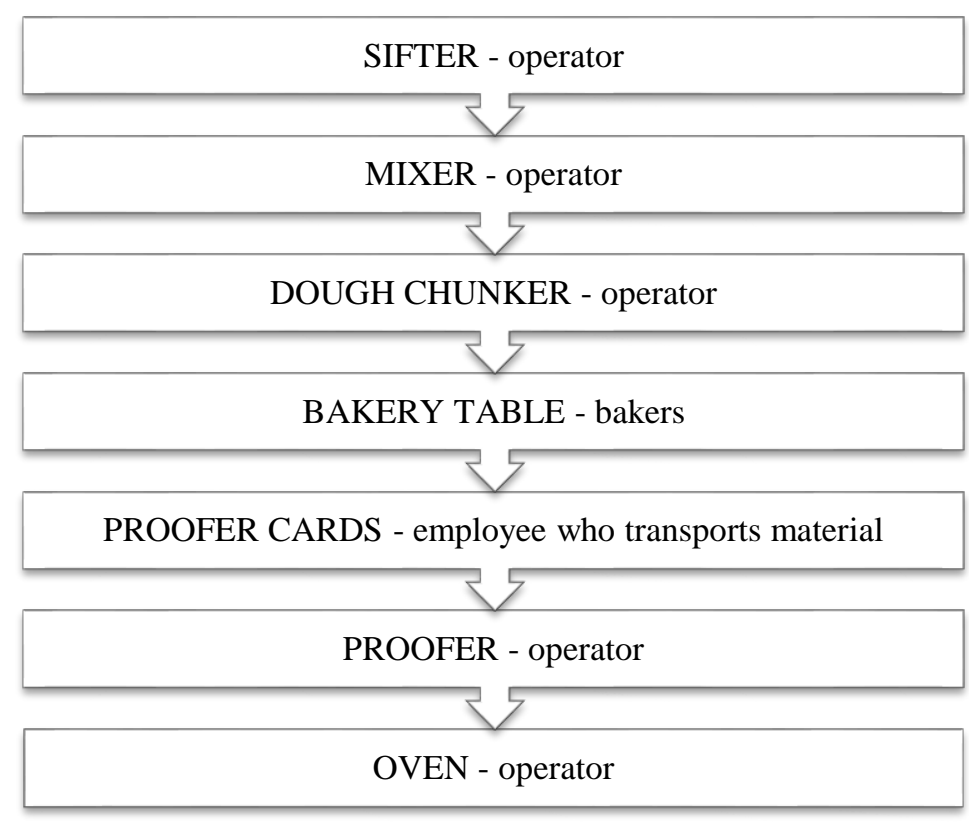

Figure 1. Process of production of bread in the investigated establishment

The production time on particular workstations was from 20 to 22 days (fig. 2). Losses related to retooling of devices were 1 day, except for a dough chunker, which needed 2 days for retooling. While, the biggest number of stoppages as a result of faults, concerned a sifter which did not work for 5 days. Stoppage of the remaining devices lasted from 1 to 3 days.

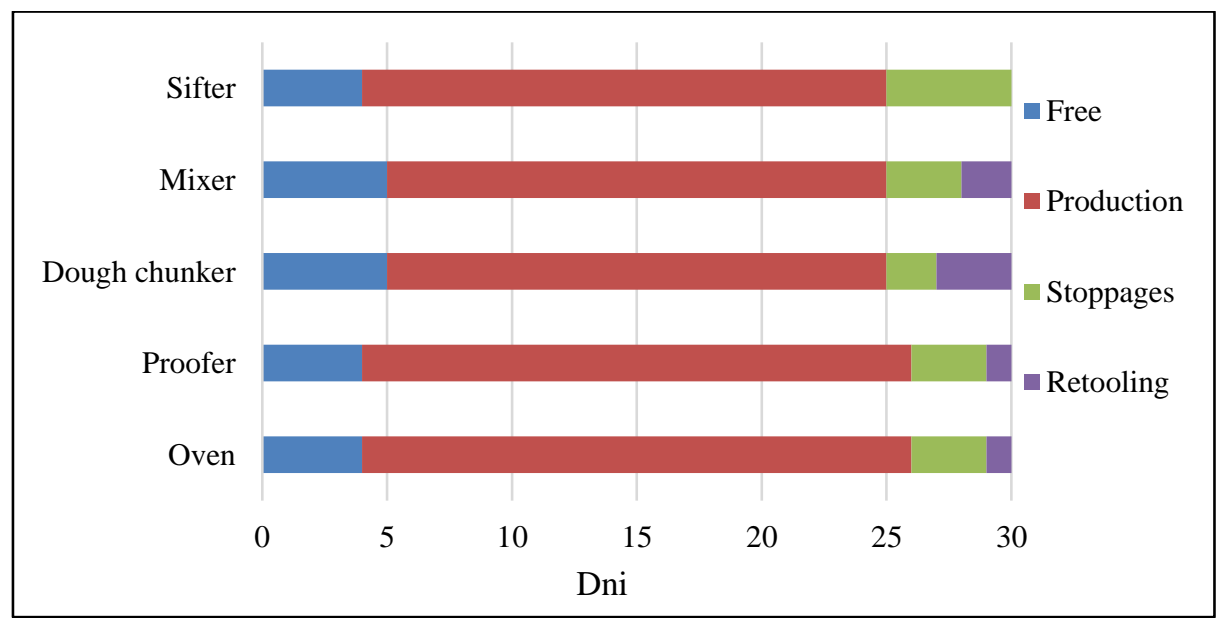

Figure 2. Range and losses of working time on particular workstations (days $\cdot \mathrm{month}^{-1}$ )

The range of the nominal working time for all workstations was in total $2035 \mathrm{~h}$ which constituted $83.2 \%$ of the total working time. Stoppages had the highest impact on the losses of working time which in total were $193 \mathrm{~h}$ i.e. $9.5 \%$ of the range of the nominal time. They resulted mainly from the time of waiting for the product, changes of production materials, 
regulation of machines and devices, no free proofers, or raw materials. The time differed on particular workstations. The biggest number of stoppages was reported for a sifter $(62 \mathrm{~h})$ and the least for a dough chunker $(10 \mathrm{~h})$ which was respectively 15.3 and $2.6 \%$ of the scope of the nominal time. The remaining sources of time losses were considerably lower. The total time of retooling was only 68 h i.e. $3.4 \%$ of the nominal time (fig. 3 ).

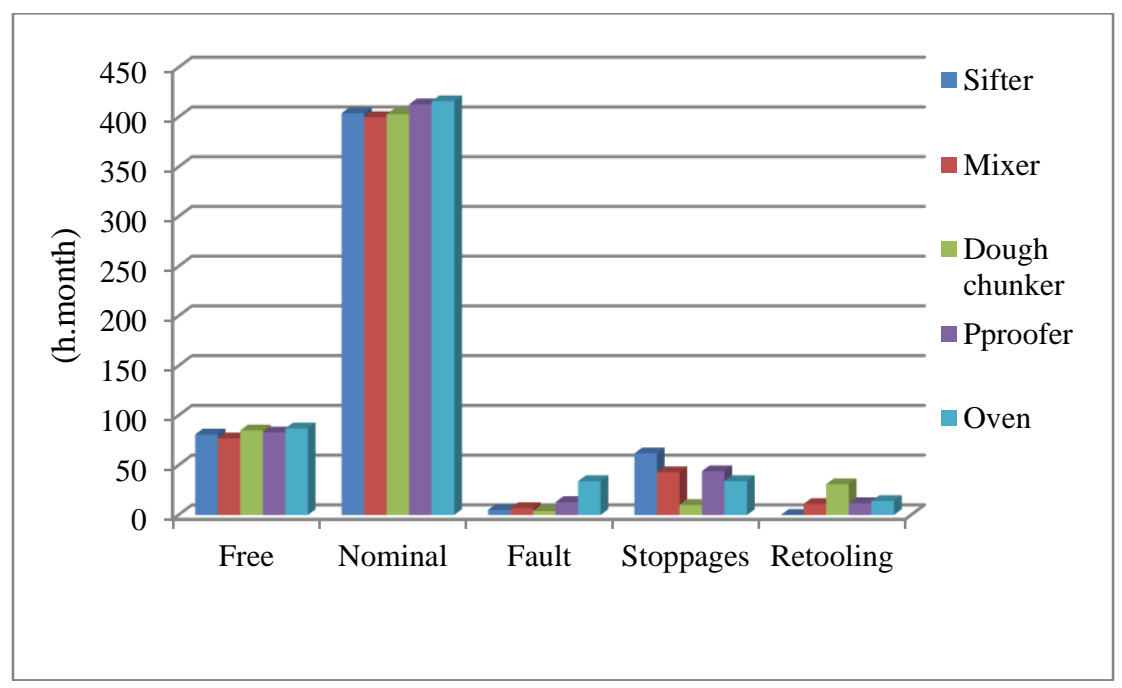

Figure 3. Range and time losses on particular stations

On the other hand, because of a fault, these losses were in total 63 h. i.e. $3.1 \%$ of the nominal time. From among the listed sources of work time losses, these losses which affect the range of the effective time should be analysed in detail. Time losses because of retooling are included therein since the process has a negative impact on the performance of the production line and thus, it increases the production costs. It happens because retooling extends the process and thus takes time. Shortening of the retooling time enables reduction of losses because of the time of waiting for retooling and preparation of tools. The essence of retooling is making the biggest possible number of operations outside the machine, during its operation.

Retooling of a dough chunker was the longest (31 h), and the mixer - the shortest $(11 \mathrm{~h})$. Retooling of these two devices was respectively 8 and $3 \%$ of the range of the nominal time. While retooling on the proofing chamber and oven were comparable and were within 12 $14 \mathrm{~h}$, thus it constituted over $3 \%$ of the range of the nominal time.

The highest technical performance over two times higher than the remaining devices was in case of a sifter (table 1). It was $2 \mathrm{t} \cdot \mathrm{h}^{-1}$ and constituted $80 \%$ of the catalogue performance. The oven was used the most i.e. $85 \%$ of the catalogue performance, and a dough chunker the least i.e. 59\%. Such a low use of this device could have resulted from significant changes of operation parameters or low performance of auxiliary processes which had a negative impact on the performance of the basic process. The range of the effective time of operation includes only the planned and justified losses of time which result from the changes of the course of production technology. While, the range of the production time is formed after the effective time fund is reduced by the non-scheduled losses resulting most often from incorrect work organization or random factors. On the analysed stations the effective time range was $371 \mathrm{~h}$ in case of a dough chunker to $404 \mathrm{~h}$ in case of a sifter. On the other hand, the production time was $334 \mathrm{~h}$ for an oven and $358 \mathrm{~h}$ for a dough chunker. Thus, in case of 
the oven, the time of production was $83.0 \%$ of the effective time range, while in case of the dough chunker as much as $96.2 \%$ (fig. 4). The highest rhythm of the production flow concerned the oven $\left(2.4 \mathrm{~h}^{\cdot} \mathrm{t}^{-1}\right)$, and the lowest - the sifter $\left(0.6 \mathrm{~h}^{-\mathrm{t}^{-1}}\right)$. On the other hand, the analysis of the hourly task proved the highest value for the sifter and the lowest for the oven - respectively 1.67 and $0.42 \mathrm{~h} \cdot \mathrm{t}^{-1}$ (tab. 1). The reason of a high result for the rhythm of the production flow and low value of the hourly task for the oven is a lengthy duration of the final baking of bread. While, the fastest process is sifting. Thus, in one hour the biggest amount of material get through the device in comparison to the remaining workstations.

Table 1. Production capacity and production reserves

\begin{tabular}{|c|c|c|c|c|c|}
\hline \multirow[b]{2}{*}{ Specification } & \multicolumn{5}{|c|}{ Workstations } \\
\hline & Sifter & Mixer & $\begin{array}{l}\text { Dough } \\
\text { chunker }\end{array}$ & Proofer & Oven \\
\hline $\begin{array}{l}\text { Technical perfor- } \\
\text { mance }\left(\mathrm{h} \cdot \text { month }^{-1}\right)\end{array}$ & 2.00 & 1.04 & 0.67 & 0.54 & 0.51 \\
\hline Effective time (h) & 404 & 389 & 371 & 400 & 402 \\
\hline Production time $(\mathrm{h})$ & 337 & 340 & 358 & 543 & 33 \\
\hline $\begin{array}{l}\text { Manufacturing } \\
\text { capacity (h) }\end{array}$ & 808 & 403 & 250 & 216 & 205 \\
\hline Production (t) & 675 & 351 & 240 & 185 & 170 \\
\hline $\begin{array}{l}\text { Production reserves } \\
\text { (t) }\end{array}$ & 134 & 52 & 9 & 31 & 35 \\
\hline $\begin{array}{l}\text { Rhythm of produc- } \\
\text { tion flow } \\
\left(\mathrm{h} \cdot \text { month }^{-1} \text { ) }\right.\end{array}$ & 0.60 & 1.11 & 1.55 & 2.16 & 2.36 \\
\hline $\begin{array}{l}\text { Hourly task } \\
\left(\mathrm{h} \cdot \mathrm{month}^{-1}\right)\end{array}$ & 1.67 & 0.90 & 0.65 & 0.46 & 0.42 \\
\hline
\end{tabular}

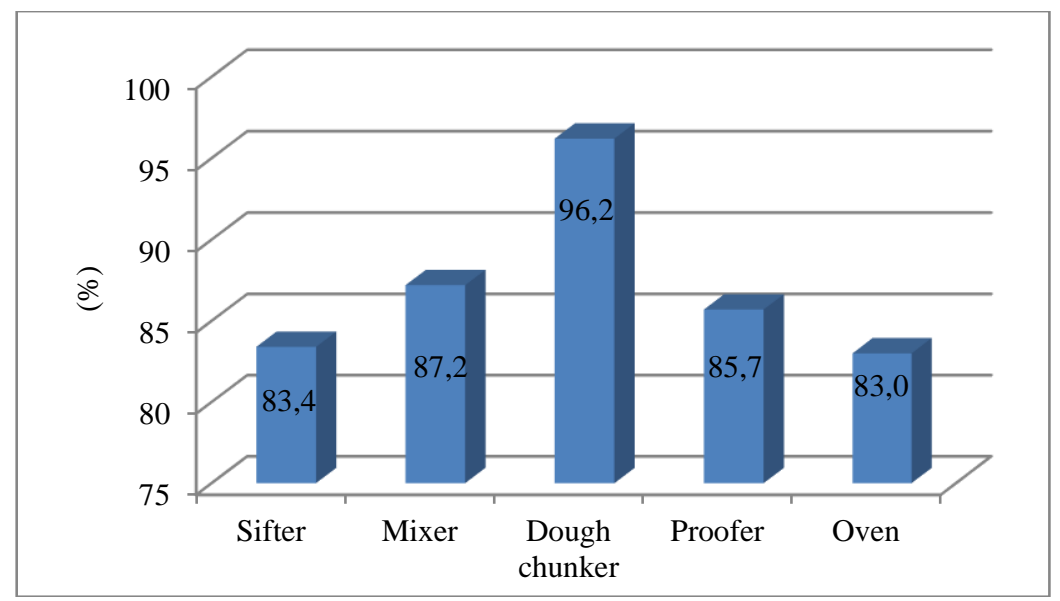

Figure 4. Use of production capacity of devices

The production capacity which is a product of the effective time and technical performance for the dough chunker, proofer and oven was at a similar level and was respectively: 250, 216 and $205 \mathrm{~h}$. While, it decisively diverged from the production capacity of the oven which was $808 \mathrm{~h}$. Therefore, it was several times higher than the remaining devices which constitute the production line. 


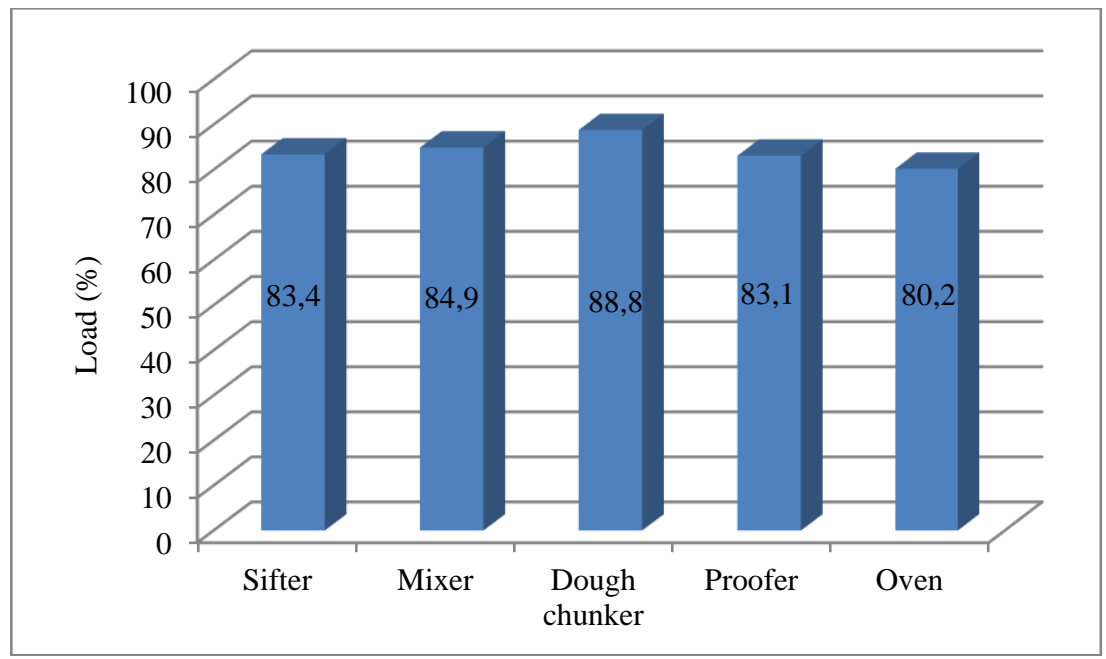

Figure 5. Loading of workstations

Loading of workstations as a ratio of the production time to the nominal time was within $80.2 \%$ and $88.8 \%$ (fig. 5). The highest load concerned the station with a dough chunker and the lowest was in case of the oven. Loading of the remaining stations was comparable, which indicates a high relation of particular workstations. Such stiff relations are characteristic for continuous lines for which any stoppages and periodical shut offs must be loosely synchronised with each other.

\section{Summary}

Analysis of the assessed production line indicates the use of the continuous work system and a high level of production balancing. $170 \mathrm{t}$ of bread was produced in the investigated period.

On particular stages of production, the production capacity was from $808 \mathrm{~h}$ for a sifter to $205 \mathrm{~h}$ for the oven. In the entire production process, the most synchronised and balanced are the proofing stages and the final baking.

The biggest use of the production capacity was reported in the implementation stage and dough division where it was $96.2 \%$. On the other hand, the lowest use of the production capacity was in case of the oven $-83 \%$. To obtain the production capacity of particular stages, it is necessary to increase the technical performance of machines and devices, including particularly the oven and proofer.

A low level of differentiation of loading of particular workstations which is from $80.2 \%$ to $88.8 \%$ proves high mutual relations between particular stations, characteristic for continuous lines and a high effectiveness of operation. For such lines, any stoppages and shut offs must be strictly synchronised which reduces threats of not performing the production schedule.

\section{References}

1. M. Zemczak, Production orders scheduling in multiversion and multiassortment production systems. Part 1. Wyb. Probl. Inż., 379-384. (2013). 
2. Z. Kowalczyk, M. Cupiał, Estimation methods of the agricultural equipment value with regard to evaluation of Alina carrot harvester. Contemporary Research Trends in Agricultural Engineering BIO Web Conf., $10 \quad$ (2018) 01011. https://doi.org/10.1051/bioconf/20181001011. (2018).

3. Stabryła Analiza zdolności rozwojowej przedsiębiorstwa w kontekście innowacyjności. Stud. Ekon. 183, 173-184. (2014).

4. W. Zielecki, J. Sęp, Supporting the design of U-shaped production lines using the network programming method. Innowacje w Zarządzaniu i Inżynierii Produkcji, 1(4), 682-688. (2014).

5. U. Malaga-Toboła, S. Tabor, D. Kwaśniewski, M. Kuboń Production capacity and workstations load in the animal feed production process. Agricul. Eng., 20(1), 91-100. (2016).

6. R. Magda, Wpływ stopnia wykorzystania zdolności produkcyjnej zakładu górniczego na jednostkowy koszt własny. Oficyna Wydawnicza Polskiego Towarzystwa Zarządzania Produkcją. 290-300. (2014).

7. E. Staniewska, Improvement of the metallurgical enterprise production proces. Logistyka, 2, 720-727. (2015).

8. Burduk, D. Górnicka, Improving material flow and deployment of production stations on the example of a small manufacturing company. Gosp. Mat. i Log., 6, 23-43. (2016).

9. M.P. Brundage, Q. Chang, Y. Li, J. Arinez, G. Xiao, Sustainable manufacturing performance indicators for a serial production line. IEEE Trans. on Autom. Scien. and Eng., 13(2), 676-687. (2016).

10. J. Lewandowski, B. Skołud, D. Plinta, Organizacja systemów produkcyjnych. Polskie Wydawnictwo Ekonomiczne, Warszawa. ISBN 978-83-208-2148-2. (2014).

11. M. Kuboń, A. Krasnodębski, Logistic cost in competitive strategies of enterprises. Agric. Econ. 56. 397-402. http://www.agriculturejournals.cz/pubicFiles/ 25303.pdf. (2010).

12. J. Matuszek, D. Kurczyk D. Designing processes and production systems using computer virtualization technology. Innow. w Zarz. i Inż. Prod., 2(12), 741-752. (2017).

13. Y. Ojaghi, A. Khademi, N. M. Yusof, N.G. Renani, S.A.H. Hassan, Production layout optimization for small and medium scale food industry. Procedia CIRP, 26, 247-251. (2015).

14. Kutschenreiter-Praszkiewicz, Assembly process layout planning of customized products. Gosp. Mater. i Log., 4, 2-13. (2019).

15. J. Matuszek, T. Kasperek, Rationalization of workplaces changeover times. Org. i Zarz., 70, 287-299. (2014).

16. U. Malaga-Toboła, S. Tabor, S. Kocira, Productivity of resources and investments at selected ecological farms, w: Farm machinery and processes management in sustainable agriculture, 7th International Scientific Symposium / Huyghebaert Bruno, Lorencowicz Edmund, Uziak Jacek (red.), Agriculture and Agri-cultural Science Procedia, 7, Elsevier, ss. 158-164, DOI:10.1016/j.aaspro.2015.12.011. (2015).

17. M. Dłużewski (red.), Technologia żywności. Warszawa, WSiP, ISBN 978-83-0207978-8. (2008). 